International Journal of Health Sciences
Available online at www.sciencescholar.us
Vol. 6 No. 1, April 2022, pages: 267-276
e-ISSN: 2550-696X, p-ISSN: 2550-6978
https://doi.org/10.53730/ijhs.v6n1.4015

\title{
Labor Training in Design and Technological Activities of Students
}

\author{
(1) CrossMark \\ Yuliia Sribna a, Tetiana Borysova ${ }^{b}$, Ihor Savenko c, Yurii Kaliazin d, Valerii Tytarenko e, \\ Nataliia Svyrydiuk ${ }^{\mathrm{f}}$
}

Manuscript submitted: 19 September 2021, Manuscript revised: 9 December 2021, Accepted for publication: 13 January 2022

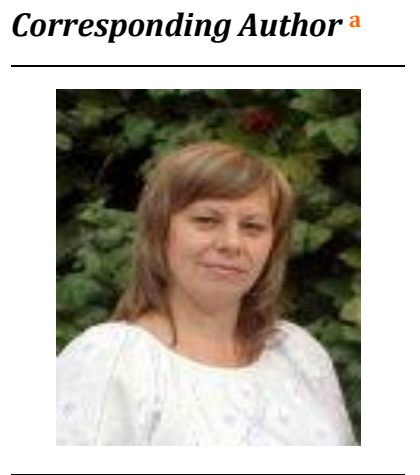

Keywords

educational environment;

educational process;

educational sphere;

educational technology;

labor training;

practical work;

schoolchildren education;

technical modeling;

technological activities;

\begin{abstract}
The aim of the study is analyzing of labor training in the design and technological activities of students in the current educational environment, the pedagogical technologies that can purposefully influence the development of intellectual activity and creative potential of students must be the leading ones. One of these in the educational sphere is design and technological activity, which is one of the priorities in labor training. The relevance of the research is in the discourse of ways and forms of hypothesis is that the introduction of design and technology activities to the labor training contributes to increasing the level of students' success and develops practical skills by involving them in active creative work and socially beneficial activities.
\end{abstract}

International Journal of Health Sciences (C) 2022. This is an open access article under the CC BY-NC-ND license (https://creativecommons.org/licenses/by-nc-nd/4.0/).

\section{Contents}

Abstract

1 Introduction

2 Materials and Methods

3 Results and Discussions

a Poltava V. G. Korolenko National Pedagogical University, Poltava, Ukraine

b Poltava V. G. Korolenko National Pedagogical University, Poltava, Ukraine

c Poltava V. G. Korolenko National Pedagogical University, Poltava, Ukraine

d Poltava V. G. Korolenko National Pedagogical University, Poltava, Ukraine

e Poltava V. G. Korolenko National Pedagogical University, Poltava, Ukraine

f Poltava V. G. Korolenko National Pedagogical University, Poltava, Ukraine 


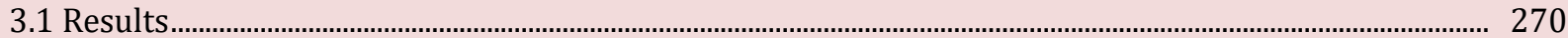

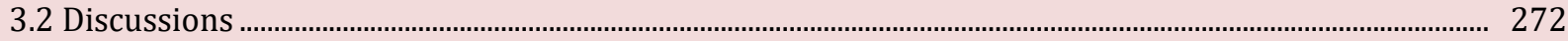

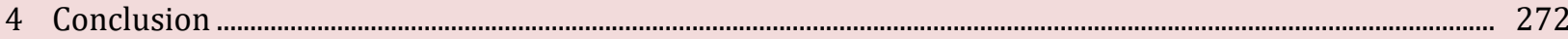

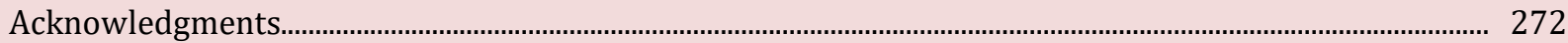

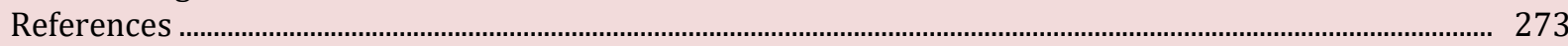

Biography of Authors .................................................................................................................................... 275

\section{Introduction}

A constant interaction between theory and practice, a body of knowledge and tasks that require practical experience (Way, 2016; Shin, 2018), characterize the creative process. In the field of labor training for ensuring creative technical activity is necessary theoretical training of students, providing them with a system of knowledge and skills on the ways of construction, technologies for performing practical tasks, ways to solve them using creative abilities and technical knowledge (Fernández-Manjón et al., 2007; Arbol, 2018; dos Santos et al., 2020). In addition, this is a relevant topic for modern research in the field of pedagogy. Education of the creative worker, which is qualified and initiative, contributes to the effectiveness of creative work in general. The relevance is in the review of ways to form in pupil's skills and skills of working with tools and materials, the search for the most effective ways to perform complex technical operations by schoolchildren. The problematic issue is the approaches to the design and technological activities, education of a strong commitment of students in the creation and implementation of projects: whether it should be carried out continuously, or it can be implemented intermittently, divided into several series (Solemani et al. 2015). A further consideration is required mechanism of formation and development of motivation, involvement of intellectual and practical activity with the help of project technologies (Estriegana et al., 2019; Sani, 2014). Today, educators are very concerned about the development of the mechanism of project activities in learning modern technology, its effectiveness and impact on motivation, cultivating a strong interest in work training, the implementation of project technologies in the educational environment (Ozer \& Akgun, 2015; del Carmen Ortega-Navas, 2017).

\section{Literature review}

The technological revolution and technological growth in the modern world and the need to continually improve the educational process have contributed to the fact that project technology is well known in the pedagogical literature. These are especially the works (Dewey, 1986), as well as the current research on project technology (Kiki-Papadakis \& Chaimala, 2016; PACTE, 2018). The study focuses on the educational teacher (Peterson \& Nassaji, 2016), the use of interactive methods, Designing as an activity under conditions of accelerated technological changes, where human capital is not canceled, but guarantees the effective use of technology (Acemoglu \& Zilibotti, 2001). The use of design and technology activities has been the focus of attention of researchers from various positions: learning mechanics in production (Dearden et al. 2006), technological activity as a method of formation of permanent motivation for project activities (CASLS, 2019), implementation of project technologies in high schools (Senthilkumar \& Kannappa, 2017; Makarenko, 2020), the implementation of project activities in education on the productivity of professional growth, the link between training and the professional level of European employees were investigated (Temple, 2006; Albert et al., 2010).

An integrated approach to work in classrooms, workshops, where practical tasks and theory of workbased learning are combined, as well as personality and mastery on the success of the project activities, is considered (dos Santos et al., 2020). In addition, the problem of the active involvement of all participants in the educational process in the work, teaching, and preparation of project documentation was investigated (Puranik, 2020). The project method was seen as an effective factor in the study through project activities (Way, 2016; Kadir et al., 2021). There has been a review of the components of design, conditions of successful implementation of innovative technologies in the teaching experience (Salinas, 2007; PACTE, 2018).

A special focus is the study of the ways of active implementation of professional self-identification in the labor lessons (Vasenko, 2021). The design-technological activity provides practical possibilities for realizing 
the intellectual potential of the student and is an effective educational technology in the middle school disciplines; it promotes collaboration between teachers and students, develops teamwork skills, and fosters a strong interest in production technology (CASLS, 2019; Sedeghi et al., 2016). In the current research of the mechanisms and conditions of implementation of design and technological activities, the work on the humanization of technology is being carried out. The educational process has been made close to the students by involving all the participants in the educational process inactive project activities (Shin, 2018; Javadi \& Tahmasbi, 2020).

Lack of research remains the modeling of design and technological activities, the frequency and methods of education of schoolchildren with a strong interest in labor education, the beginning of formation and development of critical thinking, skills of self-study (Shtepa et al., 2015; Lubart et al., 2010). In future research, the practice of pedagogical experimentation in the field of developing practical skills in high technologies, forming social and personal responsibilities of people in the society should be continued. The existing research in design activity, it can be argued that the introduction of design-technological activity to the educational process, especially to the labor training of secondary education students is not fully developed (Barzylovych et al., 2020; Chang et al., 2020).

\section{Materials and Methods}

An innovative educational project was implemented, which was implemented by the state educational institution (Regional Center of Professional Education in Innovative Technologies of Building and Industry (Kharkiv professional lyceum of building technologies), Ukraine). The project involved 24 participants who participated in the academic year (2 semesters) course "Technology" for electrical installation and construction specialties.

Stage 1. On the first stage, the first step of the project was set: its structure and components were determined, active discussion of organizational aspects was held with the students, project skills were formed. Then there was determined what technology and what kind of product will be presented by the project. The entire project was formed of three stages and consisted of six stages (general introduction to the project, identification of problems and needs, the generation of ideas and selection of the best for further implementation, implementation of the project, the creation of products, technical documentation, project presentation, analysis, and reflection).

Students independently select project objects within the scope of the academic topic, information sources (work-study guide or collection of their materials for the project), and the educational platform.

Stage 2. Materials for labor training within the boundaries of the course "Technology" before working actively on the project, introducing new technologies and ways of their implementation in practical activities. The teacher for the status and technical readiness of the project constantly monitors each project group. Some components of the project are defined, the works are developed, models, technical documentation, assistance in mastering the technology of labor (Cantwell \& Piscitello, 2002; Ma et al., 2009). The edges are made in a better provision of material and technical components of the project, is formed and evolves design of the project, is made by design, planning, distribution of roles, and consistency of the content areas of the project. At this stage, the teachers are questioned about their prospects for implementing design and technological activities at labor lessons, i.e. the design technology is evaluated in terms of its feasibility for continuous use in the teaching process.

Step 3. At the final stage, the students' knowledge was monitored and the respondents were evaluated on the implementation of project technologies.

Sribna, Y., Borysova, T., Savenko, I., Kaliazin, Y., Tytarenko, V., \& Svyrydiuk, N. (2022). Labor training in design and technological activities of students. International Journal of Health Sciences, 6(1), 267-276. 


\section{Results and Discussions}

\subsection{Results}

The experimental class (24 students) was grouped into creative groups, and the grouping was based on the needs of the students. Each group consisted of 8 students aged 15-16. These students were graduates of the 1st year 2020-2021 academic year in the program "Electrician of power and electrical installation, an electrician with lighting and lightning measures", "Mason of plasterboard structures, painter, and plasterer. The project involved 5 teachers who teach the course "Technology" and are responsible for the implementation of labor training in the school.

Students have already had a general idea of electrical installation and installation of lighting systems, but had not previously used it in the educational courses of design and technology activities. Parallel to the design activity was used educational literature on theory. The level of success of each student depended on his or her contribution to the project and the quality and relevance of the product presented (Chaika et al., 2021).

Moreover, the implementation of design-technological activities is composed of some components, the interaction of which allows for effective implementation of design technology in labor education. The components of design-technological activity are based on the formation of a set of competencies of students: the ability to find, use and analyze information, plan their activities, improve communicative skills, skills of group work, and management of creative technological projects, etc. All components of the design and technological activities require the active involvement of students in the process of familiarization and involvement in the life of manufacturing technology. Only under these conditions, the project will be interesting and exciting for students, design and technological activity is to develop a strong interest in job training.

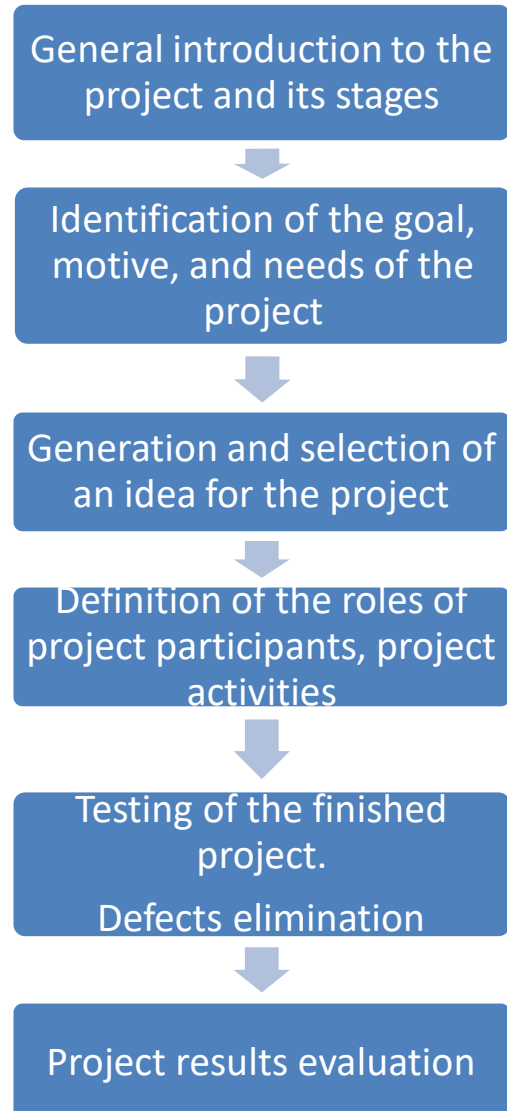

Figure 1. The main stages of the research project (author's elaboration) 
At the next stage (2 stages) of the project implementation, teachers were polled to assess their interest in the continuation of labor education using project technology.

Table 1

Evaluation of design and technology use during the lessons by labor teachers

\begin{tabular}{llll}
\hline & & Yes & No \\
\hline 1 & Plan to continue project-based programs in labor training & $76 \%$ & $24 \%$ \\
2 & $\begin{array}{l}\text { Design and technology activities contribute to positive impressions of the } \\
\text { labor activity }\end{array}$ & $92 \%$ \\
3 & $\begin{array}{l}\text { The teacher's assistance is essential for students and contributes to } \\
\text { successful project activities }\end{array}$ & $56 \%$ \\
4 & The project has changed the attitude to work instruction for the better & $62 \%$ & $38 \%$ \\
\hline
\end{tabular}

As we can see, the most positive reaction was caused by the fact that the project activity positively influences the students' positive impressions of the labor training. This means that a positive image of work training is formed and motivation of students is increased.

The results are presented in a 100-point system. The evaluation was carried out according to the following criteria: basics of design - the ability to create a design project, the ability to coordinate in the stage implementation of the project; objectives - the ability to identify the relevance, purpose and objectives of the design and investigative work; creative work - skills of non-standard solution of technological problems of the project; ability to plan a specific product, use technologies for its creation; knowledge of technologies - range of production technologies, which the student knows and uses in practice.

\section{Comparative Analysis of the Results}

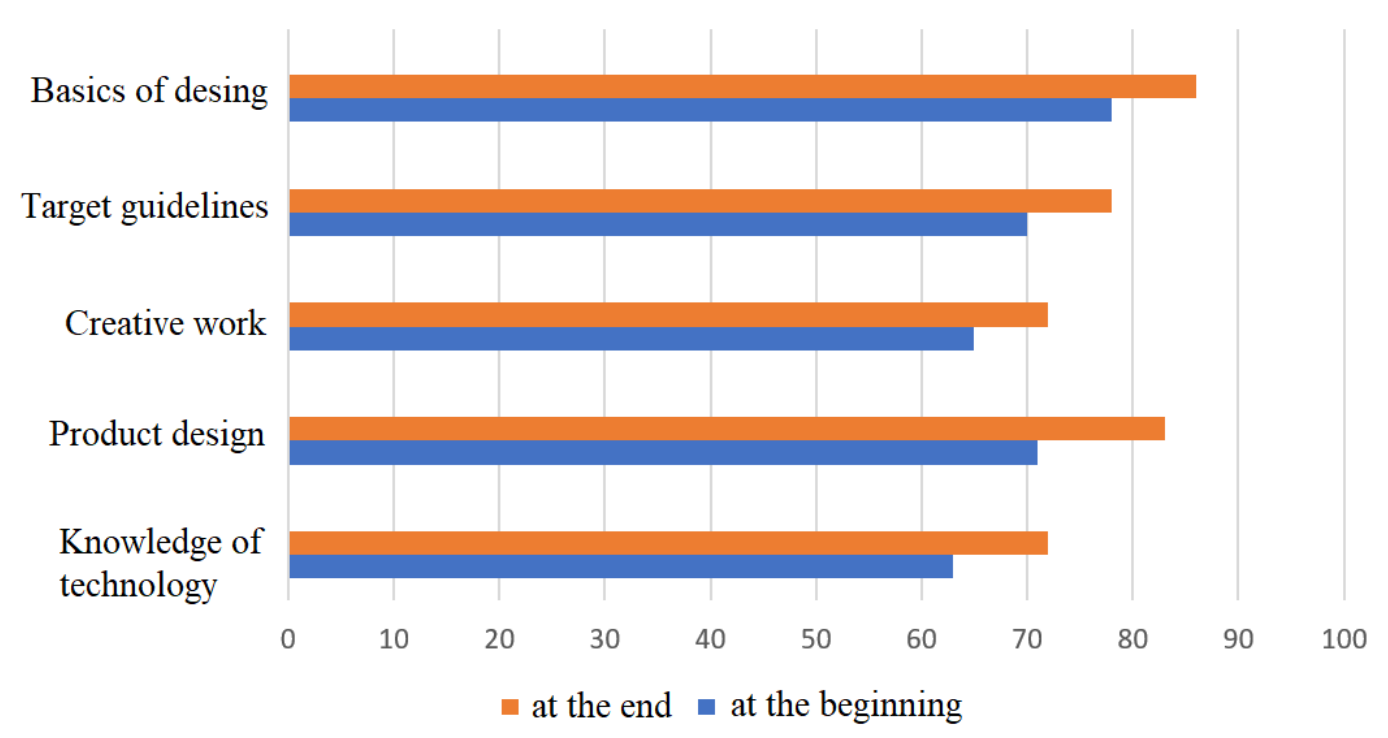

Figure 3. Summarizing projects in educational discipline "Technology" (author's elaboration)

According to the data presented, the general perception of design and technological activities is positive, and it becomes an effective factor. Overall, scores for the course "Technology" increased by $10 \%$, especially students are given the proper mechanics of the project and the identification of problems and needs for implementation in the project.

Sribna, Y., Borysova, T., Savenko, I., Kaliazin, Y., Tytarenko, V., \& Svyrydiuk, N. (2022). Labor training in design and technological activities of students. International Journal of Health Sciences, 6(1), 267-276. https://doi.org/10.53730/ijhs.v6n1.4015 


\subsection{Discussions}

The pedagogical field has a small number of experimental studies. Pedagogical experiment that investigated the algorithm of project technology implementation in the teaching process (Meri-Yilan \& Konca, 2021), shows, the implementation basics of translation and studying English and Turkish increased the students' motivation, improved their attitude toward learning, and improved their attitude toward traditionally difficult courses. Almost $70 \%$ of respondents at the end of the experiment technology activities in training; indicated that the skills and knowledge have increased, new perspectives to self-advocacy have emerged. The participants of the experiment hope for further continuation of the training with the use of project technology (Weiss et al., 2005; Iwanaga et al., 2021). Our research also revealed that $92 \%$ of teachers believe that project technology activities are beneficial for the formation of positive image of labor lessons, and $76 \%$ of teachers plan to continue using project technology in their future professional activities.

The research on the implementation of technical modeling in the design and technological activities of students (Vasenko, 2021), showed that active use of such activities contributes to the development of creative potential of schoolchildren. In the experimental class where design and technology activities were actively used during the year, the number of students with a high level of creativity was $8-10 \%$ higher on average. In our research we have also seen a $10 \%$ increase in the level of students' success within the framework of the teaching discipline "Technology" due to the introduction of design and engineering activities to the labor training process (Diachenko et al., 2021; Widana et al., 2021).

\section{Conclusion}

It is possible to realize creative and intellectual potential of students at labor lessons design technological activities educational, which creates conditions for the preparation of technically educated specialist and contributes to increasing the motivation for learning and practical activities. The use of interactive teaching methods and modern production technologies in labor training contributes to the formation of a strong interest of students in the interactive activities and forms a positive attitude of teachers to the implementation of innovative methods. The activation of design and technological activities was positively received by the teachers who worked on the project: teachers were encouraged to constantly implement project technology in the process of labor training; to work on the formation of a strong desire in students to engage in project activities in the framework of practical cases; not to be afraid to realize their creative potential.

Humanization labor training, project activities, and the interest of teachers in the implementation of such research demonstrates the need for implementation of innovative technologies in the current system of secondary education. The practical importance lies into establishing the effectiveness of the implementation of labor training in schools design and technological activities as allowed forming practical and technological skills and active involvement in the intellectual and creative potential of students.

The implementation of pedagogical experiments at labor education classes at secondary vocational and secondary special education institutions is promising in the future, which focus on the implementation of pedagogical innovations. An important part of such studios in the kingdom of pedagogy must remain designtechnological activity as an effective way to form creative and intellectual abilities of students.

Acknowledgments

We are grateful to two anonymous reviewers for their valuable comments on the earlier version of this paper. 


\section{References}

Acemoglu, D., \& Zilibotti, F. (2001). Productivity differences. The Quarterly Journal of Economics, 116(2), 563606.

Albert, C., GARCÍA-SERRANO, C., \& Hernanz, V. (2010). On-the-job training in Europe: Determinants and wage returns. International Labour Review, 149(3), 315-341.

Arbol del, E.V. (2018). Innovative Teaching Methods in Specialised Translation, Modern Journal of Language Teaching Methods, 8(12), 426-436.

Barzylovych, A., Oliinyk, Y., Kostitska, I., Shakhman, N., \& Buryk, Z. (2020). Transformation of the Social and Medical Spheres under the Conditions of COVID-19. Systematic Reviews in Pharmacy, 11(11), 1328-1337.

Cantwell, J., \& Piscitello, L. (2002). The location of technological activities of MNCs in European regions: The role of spillovers and local competencies. Journal of International Management,8(1), 69-96. https://doi.org/10.1016/S1075-4253(01)00056-4

CASLS. (2019). Project-Based Language Learning: The Basics.

Chaika, O., Chahrak, N., Zhumbei, M., Apelt, H., Kopchak, L., \& Litvinova, A. (2021). Pedagogical framework for poly multicultural education of foreign language students seeking a degree in teaching. International Journal of Health Sciences, 5(3), 605-616. https://doi.org/10.53730/ijhs.v5n3.2618

Chang, M. O., Peralta, A. O., \& Corcho, O. J. P. de. (2020). Training with cognitive behavioral techniques for the control of precompetitive anxiety. International Journal of Health \& Medical Sciences, 3(1), 29-34.

Dearden, L., Reed, H., \& Van Reenen, J. (2006). The impact of training on productivity and wages: Evidence from British panel data. Oxford bulletin of economics and statistics, 68(4), 397-421.

del Carmen Ortega-Navas, M. (2017). The use of new technologies as a tool for the promotion of health education. Procedia-Social and Behavioral Sciences, 237, 2329.https://doi.org/10.1016/j.sbspro.2015.07.401

Dewey, J. (1986). Experience and education. In The educational forum (Vol. 50, No. 3, pp. 241-252). Taylor \& Francis Group.

Diachenko, A., Vusyk, H., Bielova, Y., Shurdenko, M., \& Titenko, O. (2021). The educational role in COVID-19 terms of ethnodesign graphic function in higher education practical activities. International Journal of Health Sciences, 5(3), 584-593. https://doi.org/10.53730/ijhs.v5n3.2540

dos Santos, I. T. R., Barreto, D. A. B., \& de Oliveira Soares, C. V. C. (2020). Formative assessment in the classroom: the dialogue between teachers and students.Journal of Research and Knowledge Spreading, 1(1), e11483-e11483.

Estriegana, R., Medina-Merodio, J. A., \& Barchino, R. (2019). Student acceptance of virtual laboratory and practical work: An extension of the technology acceptance model. Computers \& Education, 135, 1-14. https://doi.org/10.1016/j.compedu.2019.02.010

Fernández-Manjón, B., Sánchez-Pérez, J. M., Gómez-Pulido, J. A., Vega-Rodríguez, M. A., \& Bravo-Rodríguez, J. (Eds.). (2007). Computers and education: E-learning, from theory to practice. Springer Science \& Business Media.

Group, P. A. C. T. E., Hurtado Albir, A., Galán-Mañas, A., Kuznik, A., Olalla-Soler, C., Rodríguez-Inés, P., \& Romero, L. (2018). Competence levels in translation: working towards a European framework. The Interpreter and translator trainer, 12(2), 111-131.

Iwanaga, T., Wang, H. H., Hamilton, S. H., Grimm, V., Koralewski, T. E., Salado, A., ... \& Little, J. C. (2021). Sociotechnical scales in socio-environmental modeling: Managing a system-of-systems modeling $\begin{array}{llll}\text { approach. Environmental Modelling } \quad \& \quad & \text { Software, 135, } & 104885 .\end{array}$ https://doi.org/10.1016/j.envsoft.2020.104885

Javadi, Y., \& Tahmasbi, M. (2020). Application of humanism teaching theory and humanistic approach to education in course. Theory and Practice in Language Studies, 10(1), 40-48.

Kadir, Y. R., Syarif, S., Arsyad, M. A., Baso, Y. S., \& Usman, A. N. (2021). Female's reproductive health application design on the school teacher knowledge: an android-based learning media. International Journal of Health \& Medical Sciences, 4(2), 189-195.

Kiki-Papadakis, K., \& Chaimala, F. (2016). The Embedment of Responsible Research and Innovation Aspects in European Science Curricula. Romanian Journal for Multidimensional Education/Revista Romaneasca Pentru Educatie Multidimensionala, 8(2).

Sribna, Y., Borysova, T., Savenko, I., Kaliazin, Y., Tytarenko, V., \& Svyrydiuk, N. (2022). Labor training in design and technological activities of students. International Journal of Health Sciences, 6(1), 267-276.

https://doi.org/10.53730/ijhs.v6n1.4015 
Lubart, T., Pacteau, C., Jacquet, A. Y., \& Caroff, X. (2010). Children's creative potential: An empirical study of measurement issues. Learning and Individual Differences, 20(4), 388-392. https://doi.org/10.1016/j.lindif.2010.02.006

Ma, Z., Lee, Y., \& Chen, C. F. P. (2009). Booming or emerging? China's technological capability and international collaboration in patent activities. Technological Forecasting and Social Change, 76(6), 787-796. https://doi.org/10.1016/j.techfore.2008.11.003

Makarenko, L. L., Slabko, V. M., Bordiuk, O. M., Shpylovyi, Y. V., \& Slaboshevska, T. M. (2020). Application of design and technological activities as a method of improving the professionalization of specialists of higher educational institutions. Revista Tempos e Espaços em Educação, 13(32),

Meri-Yilan, S., \& Konca, M. Y. (2021). An Evaluation Of Project-Based Learning: A Turkish 'Linguistics For Translators'students'case. Ekev Akademi Dergisi, (85), 417-434.

Ozer, E. A., \& Akgun, O. E. (2015). The effects of irrational beliefs on academic motivation and academic selfefficacy of candidate teachers of computer and instructional technologies education department. ProcediaSocial and Behavioral Sciences, 197, 1287-1292. https://doi.org/10.1016/j.sbspro.2015.07.401

Petersen, C., \& Nassaji, H. (2016). Project-based learning through the eyes of teachers and students in adult ESL classrooms. Canadian Modern Language Review, 72(1), 13-39.

Puranik, S. (2020) Innovative teaching methods in higher education. BSSS Journal of Education, IX (I), 67-75.

Sadeghi, H., Biniaz, M., \& Soleimani, H. (2016). The impact of project-based language learning on Iranian EFL learners comparison/contrast paragraph writing skills. International Journal of Asian Social Science, 6(9), 510-524.

Salinas, M.-J. (2007). How New Technologies Improve Translation Pedagogy.

Sani, S. S. (2014). Teachers' purposes and practices in implementing practical work at the lower secondary school level. Procedia-Social and Behavioral $\quad$ Sciences, 116, https://doi.org/10.1016/j.sbspro.2014.01.338

Senthilkumar, V., \& Kannappa, R. (2017). Impact of Innovative Teaching and Learning Methodologies for Higher Educational Institutions with reference to Trichirappalli District. IOSR Journal of Business and Management (IOSR-JBM), 19 (7), 88-92.

Shin, M. H. (2018). Effects of Project-Based Learning on Students' Motivation and Self-Efficacy. English Teaching, 73(1), 95-114.

Shtepa, Y., Bazhenov, R., Smirnova, A., Filippova, G., \& Vashakidze, N. (2015). Tasks in Information Modelling as Development Means of Schoolchildren's Creative Abilities. Procedia-Social and Behavioral Sciences, 214, 3-9. https://doi.org/10.1016/j.sbspro.2015.11.586

Soleimani, H., Rahimi, Z., \& Sadeghi, H. (2015). Project-Based Learning and Its Positive Effects on Iranian Intermadiate EFL Learners Reading Ability and Vocabulary Achaivement. International Journal of English Language and Literature Studies, 4(1), 1-9.

Temple, J. (2006). Aggregate production functions and growth economics. International Review of Applied Economics, 20(3), 301-317.

Vasenko V. (2021). Technical modeling in design and technological activity of schoolchildren. East European Scientific Journal, vol. 5(69), 17-23. http://doi: 10.31618/ESSA.2782-1994.2021.3.69.59

Way, C. (2016). Translations| The Challenges and Opportunities of Legal Translation and Translator Training in the 21st Century. International journal of communication, 10, 21.

Weiss, J. A., Gardiner, J. C., Ellis, B. J., Lujan, T. J., \& Phatak, N. S. (2005). Three-dimensional finite element modeling of ligaments: technical aspects. Medical engineering \& physics,27(10), 845-861. https://doi.org/10.1016/j.medengphy.2005.05.006

Widana, I.K., Sumetri, N.W., Sutapa, I.K., Suryasa, W. (2021). Anthropometric measures for better cardiovascular and musculoskeletal health. Computer Applications in Engineering Education, 29(3), 550561. https://doi.org/10.1002/cae.22202 


\section{Biography of Authors}

\begin{tabular}{|c|c|}
\hline 84 & $\begin{array}{l}\text { Yuliia Sribna } \\
\text { Candidate of pedagogical sciences, Senior lecturer of the department of theory and } \\
\text { methods of technological education at Poltava V. G. Korolenko National } \\
\text { Pedagogical University. } \\
\text { ORCID identifier: } 0000-0003-3846-3871 \\
\text { Email: usribna75@gmail.com }\end{array}$ \\
\hline & $\begin{array}{l}\text { Tetiana Borysova } \\
\text { Candidate of Pedagogical Sciences, Associate Professor of the Department of the } \\
\text { Fundamentals of Production and Design Poltava V.G. Korolenko National } \\
\text { Pedagogical University. } \\
\text { ORCID identifier: 0000-0002-6013-4364 } \\
\text { Email: borisova.tanya@ukr.net }\end{array}$ \\
\hline & $\begin{array}{l}\text { Ihor Savenko } \\
\text { Candidate of Pedagogical Sciences, Associate Professor of the Department of the } \\
\text { Fundamentals of Production and Design, Poltava V.G. Korolenko National } \\
\text { Pedagogical University. } \\
\text { ORCID identifier: 0000-0002-9742-5827 } \\
\text { Email: iv_savenko@ukr.net }\end{array}$ \\
\hline & $\begin{array}{l}\text { Yurii Kaliazin } \\
\text { Candidate of technical sciences, Associate Professor of the Department of the } \\
\text { Fundamentals of Production and Design, Poltava V.G. Korolenko National } \\
\text { Pedagogical University. } \\
\text { ORCID identifier: 0000-0003-4229-1953 } \\
\text { Email:yurvlad50@ukr.net }\end{array}$ \\
\hline & $\begin{array}{l}\text { Valerii Tytarenko } \\
\text { Candidate of pedagogical sciences, Senior lecturer of the department of production } \\
\text { and information technologies and life safety at Poltava V.G.Korolenko National } \\
\text { Pedagogical University. } \\
\text { ORCID identifier: } 0000-0003-2362-2876 \\
\text { Email: are1lav73@gmail.com }\end{array}$ \\
\hline
\end{tabular}

Sribna, Y., Borysova, T., Savenko, I., Kaliazin, Y., Tytarenko, V., \& Svyrydiuk, N. (2022). Labor training in design and technological activities of students. International Journal of Health Sciences, 6(1), 267-276. https://doi.org/10.53730/ijhs.v6n1.4015 


\begin{tabular}{|l|l|}
\hline & $\begin{array}{l}\text { Nataliia Svyrydiuk } \\
\text { Postgraduate student in the department of fundamentals of production and design } \\
\text { at the faculty of technology and design at Poltava V.G. Korolenko National } \\
\text { Pedagogical University. } \\
\text { ORCID identifier: 0000-0002-0983-2116s } \\
\text { Email: nata.motanka@gmail.com }\end{array}$ \\
\hline
\end{tabular}

